\title{
RESERVA E REFORMA NO EXÉRCITO PORTUGUÊS OS NÚMEROS E AS RECONFIGURAÇÕES
}

\section{RESERVE AND RETIREMENT IN THE PORTUGUESE ARMY THE NUMBERS AND THE RECONFIGURATIONS}

\author{
Ana Romão \\ Centro de Investigação da Academia Militar (CINAMIL) \& Centro Interdisciplinar de Ciências Sociais \\ (CICS.NOVA). Av. Conde Castro Guimarães, 2720-113 Amadora, Portugal. Email: anaromao74@gmail.com
}

\begin{abstract}
Maria da Saudade Baltazar
Departamento de Sociologia, Escola de Ciências Sociais, Universidade de Évora \& Centro Interdisciplinar de Ciências Sociais (CICS.NOVA.UÉvora) \& Centro de Investigação da Academia Militar (CINAMIL). Largo dos Colegiais, 2, 7000-812 Évora, Portugal. Email: baltazar@uevora.pt
\end{abstract}

\section{David Pascoal Rosado \\ Centro de Investigação da Academia Militar (CINAMIL) \& Universidade Europeia. Av. Conde Castro Guimarães, 2720-113 Amadora, Portugal. Email: david.rosado@academiamilitar.pt}

\section{Dinis Fonseca}

Centro Interdisciplinar de Ciências Sociais, Universidade de Évora (CICS.NOVA.UÉvora) \& Centro de Investigação da Academia Militar (CINAMIL). Largo dos Colegiais, 2, 7000-812 Évora, Portugal. Email: dmvfonseca@gmail.com

\section{Helga Santa Comba Lopes}

Centro de Investigação da Academia Militar (CINAMIL). Av. Conde Castro Guimarães, 2720-113 Amadora,

Portugal. Email: helga.lopes@academiamilitar.pt

Resumo: As Forças Armadas portuguesas confrontam-se com um problema clássico das organizações militares: atrair, formar, reter e preparar a saída dos homens e mulheres que compõem a força. Problema clássico, porém, sempre reatualizado na confluência das mudanças globais repercutidas no setor da Defesa e respetivos contextos sociais e políticos. O presente artigo descreve os movimentos de saída da atividade, por via da passagem à reserva/reforma dos militares de carreira do Exército português. No plano teórico convocam-se modelos da profissão militar à luz dos quais tais processos adquirem sentido. O suporte empírico decorre da análise da legislação enquadrante e de dados quantitativos referentes aos militares que entre 2000 e 2016 passaram à situação de reserva/reforma, um total de 4872 indivíduos. Verifica-se que a reforma é antecedida por um período na reserva, correspondendo maioritariamente a opções individuais de antecipar a saída da carreira, especialmente quando estão iminentes alterações legislativas que afetam a condição militar.

Palavras-chave: profissão militar, reserva, reforma, Exército português.

Abstract: The Portuguese Armed Forces are confronted with a classic problem of military organizations: to attract, train, retain and prepare the exit of the men and women who compose the force. A classic but always updated problem, giving the confluence of global changes impacting on the Defense sector and its social and political contexts. This article focuses on the transition processes for reserve and retirement, presenting the conditions required to access these situations and a briefly introducing 
theoretical models of military profession in that render such processes meaningful. The empirical support is derived from the analysis of legislation and from quantitative data referring to the military that between 2000 and 2016 entered the reserve / retirement situation, 4872 individuals. Results show that retirement is preceded by a reserve period, mostly corresponding to individual options to anticipate the end of the career, especially when impending legislative amendments affect the military condition.

Keywords: military profession, reserve, retirement, Portuguese Army.

\section{Introdução}

A profissionalização das Forças Armadas (FFAA) e as profundas transformações a montante e a jusante da adoção de modelos exclusivamente profissionais tem sido objeto de múltiplas abordagens sociológicas. Já a chegada ao fim da carreira militar, nas diferentes modalidades possíveis, nos processos subjacentes, e nos impactos que se lhe associam tem merecido mais escassa atenção. Trata-se, porém, de matérias relevantes, quer em termos da organização militar, quer para os militares implicados e suas famílias e até no que respeita às ilações que se podem extrair sobre a relação civil/militar quando se aborda a reintegração social dos militares na vida civil, acompanhada ou não de uma segunda carreira.

A transição para as situações de reserva e de reforma tem subjacentes direitos sustentados em requisitos legais específicos, incontornavelmente ligados à condição militar e às necessidades das FFAA, cujas dinâmicas da globalização e consequentes imperativos de readaptação em termos de macroestrutura (tal como definida no documento estratégico Defesa 2020) vêm realçar alguns paradoxos. Os regimes de reserva e reforma constituem respostas cruciais do sistema de compensação militar, o qual na sua globalidade assenta em alcançar os objetivos de dimensão e composição da força (Asch \& Warner, 1994; Warner, 2008).

Como em outras organizações, mas com as especificidades que a literatura sociológica tem anotado, as organizações militares enfrentam as dificuldades inerentes à implementação de instrumentos de gestão dos recursos humanos capazes de atrair e reter, formar e qualificar, motivar e preparar a saída dos profissionais que chegam ao fim da carreira. Além de integrarem o sistema de recompensas inerentes ao estatuto militar, a reserva e a reforma cumprem um papel de regulação crucial do pessoal ao serviço, ao permitirem aos militares abandonar a situação de ativo, nos termos estatutários, consoante o interesse da instituição ou do próprio. Por um lado, as exigências da vida militar, especialmente nas vertentes de treino operacional e combate, requerem profissionais jovens. Por outro lado, no contexto da carreira e da sua hierarquia fixa, a saída daqueles que não são considerados adequados para a promoção é tida como uma condição necessária para renovar os quadros e manter oportunidades de 
progressão na carreira para os mais jovens. Identifica-se assim uma rigidez no tipo de gestão de carreira up-or-out suscetível de condicionar as motivações individuais para o abandono da carreira militar, dado que a profissionalização e o downsizing dos Exércitos desafiam algumas dessas regras.

As condições eletivas para que os militares de carreira possam transitar para as situações de reserva e de reforma são legalmente definidas pelo Estatuto Militar das Forças Armadas (EMFAR) cuja última revisão (Decreto-Lei n. ${ }^{\circ}$ 90/2015 29 de maio) impõe condições mais restritivas, salvaguardando, por conseguinte, um período transitório para adaptação ao novo regime.

Em termos estatutários, reserva é a situação para que transita o militar no ativo quando verificadas certas condições, podendo ficar em efetividade de serviço ou fora da efetividade de serviço. Em síntese, por opção individual, o militar pode transitar para a reserva quando cumulativamente completa 40 anos de Tempo de Serviço Militar (TSM) e 55 anos de idade; por imposição o militar passa à reserva quando ultrapassa o limite de idade estabelecido para o posto, ou quando completa o tempo máximo de permanência na subcategoria. Deste modo, o novo EMFAR restringe as condições de passagem à reserva, entre outros aspetos por alongar a contagem do TSM. Assim, o TSM necessário para aceder à situação de reserva passou de 36 para 40 anos. $\mathrm{O}$ militar pode requerer a passagem à reserva com TSM inferior, porém o tempo máximo de permanência na reserva fora da efetividade do serviço passou a ser de cinco anos, significando que ao fim desse tempo o militar passa à situação de licença sem vencimento até perfazer idade para entrada na re-

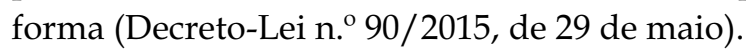

A reforma, por seu turno, é a situação para que transita o militar, estando no ativo ou na reserva. Contrariamente ao que ocorre na situação anterior, a reforma não permite o exercício de funções militares, salvo nas condições de exceção previstas (estado de sítio ou de guerra). A principal mudança introduzida no novo EMFAR vai no sentido de aproximação ao regime geral de aposentação, aumentando para 66 anos a idade de passagem obrigatória à reforma. Vigora ainda a possibilidade do militar requerer essa situação depois de completados 60 anos e mediante condições específicas, bem como a transição decorrente do militar ter completado cinco anos na situação de reserva fora da efetividade de serviço, se cumpridas condições específicas definidas nos termos do art. ${ }^{\circ} 161 .^{\circ}$ do Decreto-Lei n. ${ }^{\circ} 90 / 2015$, de 29 de maio.

O objetivo deste artigo consiste em analisar os processos de transição para a reserva/reforma e refletir sobre as motivações dos profissionais do Exército português quando abandonam a carreira militar, seja por via da passagem à reserva, seja por alcançarem a idade da reforma. 
A caracterização desses processos e a reflexão proposta tem por base resultados parcelares do projeto de investigação sobre "Carreiras dos Militares do Exército Português: Reserva e Reforma nas (re)Configurações dos seus percursos de vida - C_Mil R3", a decorrer no Centro de Investigação da Academia Militar (CINAMIL).

Para o presente paper a abordagem concentra-se no período compreendido entre 2000 e 2016, um recorte temporal particularmente significativo em termos das mudanças estruturais que afetaram as FFAA, como se verá, e que se refletem nos militares que prestam serviço no Exército, eventualmente nas respetivas opções de permanecer na vida ativa ou de antecipar o regresso à vida civil.

O universo em análise é constituído por 4872 indivíduos, correspondendo ao total de militares do Exército português pertencentes ao Quadro Permanente $(\mathrm{QP})$, que transitaram para a reserva e reforma ao longo dos primeiros 16 anos do século XXI.

Aborda-se, de um ponto de vista sociológico, este universo de militares a partir das informações disponibilizadas pela Direção de Administração de Recursos Humanos do Exército (DARH). A base de dados reúne informação sistematizada sobre os militares do QP a partir de um conjunto de variáveis de identificação (idade, género, posto, armas/serviços, ano de incorporação, data de transição e motivos para a passagem à reserva e reforma).

Esta perspetiva de análise é considerada com interesse e de utilidade para o grupo de profissionais em estudo e para a organização militar. Por um lado, pela oportunidade de análise dos dados estatísticos recolhidos, que abrange a totalidade do universo no período temporal delimitado; por outro lado por aqui se conjugar essa análise quantitativa com as alterações legislativas do EMFAR, produzidas ao longo desta série temporal de 16 anos.

A natureza das informações que integram esta base de dados, de fontes primárias oficiais, pressupõe uma análise quantitativa descritiva para determinação dos factos a considerar (Creswell, 2014; Moreira, 1994). Análise descritiva das já referidas variáveis centrais à presente pesquisa e que possibilita um primeiro retrato dos processos de transição da vida ativa para as situações de reserva e reforma no período em análise.

Para Gray (2004), a pesquisa é tida como um esforço sistemático e organizado para investigar um problema específico, e que na vertente organizacional não é uma opção fácil ao pressupor abordagens interdisciplinares incorporando ideias e premissas assentes em diversas origens e subjetivos backgrounds. E complementarmente, em organizações complexas como a militar, haverá a considerar a dificuldade no acesso às informações, constrangimento que no presente caso foi ultrapassado mediante a cedência de informação por parte da DARH no contexto do projeto C_Mil R3. 


\section{O ofício das armas: Breve contextualização teórica}

O abandono do sistema de conscrição e a sua substituição pelo modelo de profissionalização militar, a funcionar em pleno desde 2004, representou uma mudança profunda nas Forças Armadas portuguesas, concorrendo para a recomposição a que se vem assistindo desde o início do século XXI.

Na literatura sociológica, tais mudanças têm sido especialmente discutidas sob o ângulo da civilinização das FFAA, argumentando-se que a profissionalização dos Exércitos aproxima a organização militar das organizações burocráticas em geral, diluindo-se, consequentemente, o determinismo das componentes institucionais que fazem da esfera militar um mundo de normas e valores à parte. A singularidade das formas pós-modernas de organização militar caracteriza-se por quatro mudanças organizacionais decisivas: 1) interpenetração crescente entre as esferas civis e militares, do ponto de vista estrutural e cultural; 2) diminuição interna das diferenças dentro dos serviços/ramos, postos; 3) mudanças na missão, já não exclusivamente dedicadas à guerra, mas passando a integrar operações de apoio à paz e ajuda humanitária; 4) uso das forças no âmbito de forças multinacionais legitimadas por entidades que superam o Estado nação (Moskos, 2000).

Com referência ao caso francês, Caplow e Vennesson (2000) encontram cinco macrotendências no funcionamento do sistema militar, que aqui resumimos na figura 1 .

A tecnicização do ofício das armas e a metamorfose das missões assumem preponderância no contexto das mudanças no seio militar, fazendo-se sentir os seus efeitos na intensificação da formação do pessoal, na fluidez da carreira e na menor rigidez nas relações profissionais. Aspetos que no seu conjunto contribuem para a incorporação de lógicas profissionais convergentes com o que ocorre na sociedade civil, mas não forçosamente comprovativos da banalização ditada pelos fatores externos civilinizantes (Caplow e Vennesson, 2000).

Partilhando a ideia defendida por Janowitz (1975), podemos entender que a instituição militar contemporânea tendeu a desenvolver características específicas de qualquer burocracia não militar, impulsionando-a para a interdependência com a sociedade civil e modificando, por conseguinte, as suas relações sociais internas (Baltazar, 2005).

Não obstante a manutenção de traços distintivos da profissão militar, existem efetivamente semelhanças notórias entre esta e todas as outras profissões civis, por esta razão os modelos conceptuais de análise da profissão militar são similares aos adotados para as profissões civis, e que no entender de Maria Carrilho (1978) são: o estruturalista (Huntington e Janowitz), o processual (Escola de Chicago, Van Doorn e Abrahamsson) e o pluralista (Jordan, Taylor e Moskos). 


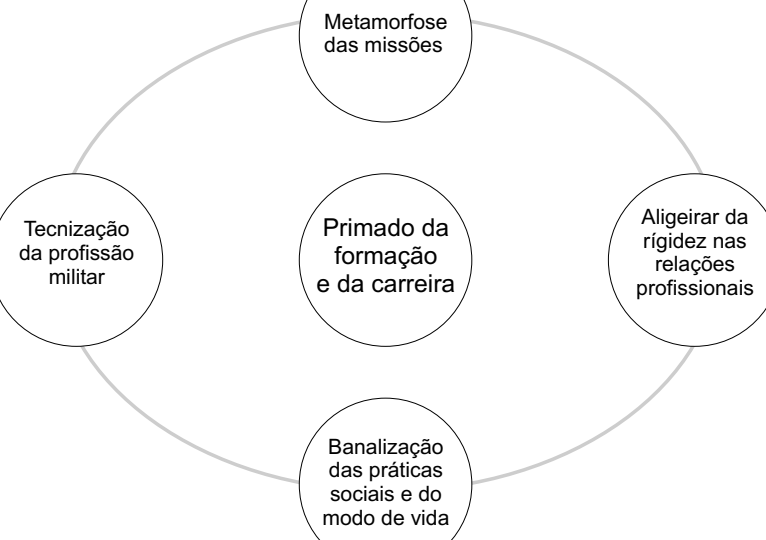

Figura 1 Tendências do funcionamento do sistema militar Fonte: Adaptado de Caplow e Vennesson (2000).

Foi neste enquadramento que Moskos $(1977,1986)$ elaborou um modelo que permite estabelecer os efeitos produzidos sobre a conceção da profissão militar pela adaptação de tarefas e de papéis militares às características da atual sociedade civil. Neste modelo, os dois tipos ideais que se apresentam de forma dicotómica o institucional e o ocupacional I/O - podem ser considerados mutuamente exclusivos ou podem coexistir traços identificativos de um e de outro numa dada força militar (Baltazar, 2005).

Face à complexidade da mudança sociocultural e sua correspondente influência na profissão militar, Nuciari (1994), defende que a análise dos atuais conteúdos desta atividade profissional, elaborada com base no modelo I / O não é suficiente, pelo que se torna, no momento, necessário considerar outros modelos que propõem uma abordagem ao nível sincrónico desta realidade.

É o caso do modelo proposto por Thomas e Prandstraller (1982), também designado por interacionista, ao considerar que as motivações racionais que impulsionam o indivíduo a ingressar nas FFAA interagem com as duas diferentes lógicas que sustentam o sistema militar (subsistema de combate e subsistema administrativo). Identifica várias estratégias de carreira, as quais manifestam uma divergente coerência face à racionalidade dual do sistema militar, e considera que a referida dualidade ao interagir com as diferentes estratégias de carreira provoca uma multiplicidade de atitudes, de orientações e de comportamentos dos profissionais militares. 
Justifica-se assim reter em perspetiva dois níveis de análise, o micro (o ator) e o macro (o sistema ou a organização militar), que por se encontrarem em constante interação provocam compatibilidades ou incompatibilidades, dependendo do tipo de estratégia e do tipo de subsistema.

Em suma, vários autores têm acentuado a variedade de fenómenos que ocorrem na organização militar, tais como: processo organizacional, propriamente dito; a posição dos profissionais nas organizações complexas; a mudança organizacional e comportamentos face aos níveis de desenvolvimento tecnológico, económico, político e sociocultural (Caforio, 1988; Nuciari, 1994; Thomas \& Rosenzveig 1982).

Compreende-se que a cultura organizacional no meio militar, ainda que acompanhando o evoluir dos tempos, não se compagine, por vezes, com a rapidez típica de algumas das mudanças sociais mais recentes. Sobretudo, urge conhecer os processos em curso, em ordem a concorrer para atingir estratégias de desenvolvimento organizacional que acalentem sinergias entre as diferentes valências da Instituição Castrense e a sua relevância social (Rosado, Romão, Baltazar, Fonseca \& Lopes, 2017).

\section{Deixar as fileiras: Rumo a uma segunda carreira, ou não ...}

O conceito de reforma encerra em si múltiplas realidades. Como instituição implica as estruturas que regulam a retirada dos trabalhadores do mercado de trabalho e a existência de um sistema de recompensas. Como processo implica decisões e padrões respeitantes à retirada da força de trabalho a partir de uma determinada idade. Como experiência refere-se à latitude de mudanças possíveis na vida decorrentes do processo (Szinovacz, 2003).

A reforma militar difere em alguns aspetos da reforma civil. Não apenas é compulsiva, como é mais precoce do que na vida civil, associando-se a isso a necessidade de garantir uma força jovem e vigorosa, bem como o encontrar de soluções em termos funcionais para a criação de vagas nos postos, prevenindo estagnação nas carreiras (McNeil, Lecca \& Wright, 1983).

Na reinterpretação que fazem dos modelos de carreira na vida civil, Sullivan, Carden e Martin (1998) encontram como principais influências no século XXI a transferibilidade de competências e os valores respeitantes ao trabalho. São fatores que a literatura também realça no caso dos militares que abandonam a carreira das armas e que tendencialmente se relacionam com a integração social e a satisfação com o novo estilo de vida.

A transferibilidade de competências para o mercado de trabalho civil, dependendo das áreas de especialidade, é então apontada como facilitadora do ajustamento 
e da satisfação com o regresso à vida civil (entre outros, Duchamp, 1990; Spiegel \& Shultz, 2003). Em sentido contrário, os entraves a essa transferibilidade, ou o facto de as novas situações profissionais implicarem perdas de prestígio, produzem impactos negativos no ajustamento e na satisfação (McNeil, Lecca \& Wright, 1983). Spiegel e Shultz (2003) acrescentam a importância que tem o planeamento/preparação para a reforma na satisfação e ajustamento à nova situação.

O reconhecimento das qualificações militares no ambiente civil pode então ser mediador das modificações de estatuto sócio profissional induzidas por uma segunda carreira, com variações consoante as especialidades mais cotadas no mercado de trabalho civil. Porém, a idade de saída tende a condicionar fortemente o sucesso da reinserção profissional (Duchamp, 1990).

No intuito de trazer à luz as interações entre as biografias, as características sociais e as lógicas profissionais dos militares, Duchamp (1990) elabora uma tipologia evidenciando a complexidade do jogo entre o tipo de qualificações, a carreira militar e a experiência de regresso à vida civil (tabela 1).

Os seis tipos ideais identificados são reveladores de reconfigurações não lineares na transição da esfera militar para a esfera civil, deixando antever também a relevância da adesão aos modelos profissionais na transição para a vida civil.

Aplicando a perspetiva dos cursos de vida ao serviço militar, Wilmoth e London (2003) referem que as consequências das transições, incluindo as que podem significar disrupções nas trajetórias estabelecidas, dependem em certa medida de serem ou não esperadas, e.g. de serem on-time ou off-time. "Se a transição ocorre no tempo culturalmente prescrito, será considerada on-time. Em contraste, as transições fora do tempo não coincidem com o esperado e frequentemente associam-se a consequências negativas" (Wilmoth \& London, 2003, p. 6).

As consequências negativas do abandono do uniforme têm merecido alguma relevância sobretudo pelo lado da psicologia, abordando dificuldades no ajustamento, ou seja, na adaptação às novas circunstâncias de vida. Retomando aqui a síntese de Tripathi (2016), as dificuldades mais frequentemente explanadas pela pesquisa empírica aludem ao inerente processo de ressocialização (Stanford, 1971), que por representar perdas no referencial de segurança que a instituição militar proporciona (Kilpatrick \& Kilpatrick, 1979) pode acarretar situações de stress (Giffen \& McNeil, 1967). Nos militares reformados identificam-se problemas de ansiedade relacionados com o emprego, redução do rendimento, mudança no enquadramento social e nas relações interpessoais, bem como outros aspetos de integração na vida civil (Bellino, 1969). Ficando libertos dos vínculos institucionais, os militares na reforma passam mais tempo em casa, podendo em alguns casos ocorrer problemas nas relações familiares (Bellino, 1970), ou mesmo disrupções (Garber, 1971). 
Tabela 1 Ensaio tipológico de comportamentos de saída da carreira militar

\begin{tabular}{|c|c|c|c|c|c|c|}
\hline \multicolumn{4}{|c|}{ Carreira Militar } & \multicolumn{3}{|c|}{ Pós-carreira Militar } \\
\hline $\begin{array}{c}\text { Tipo de } \\
\text { qualificação }\end{array}$ & $\begin{array}{c}\text { Tipo } \\
\text { de orientação(*) }\end{array}$ & $\begin{array}{l}\text { Forma } \\
\text { de saída }\end{array}$ & \begin{tabular}{|} 
Mobilidade \\
social \\
ligada \\
à carreira \\
militar
\end{tabular} & \begin{tabular}{|c|} 
Mobilidade \\
profissional \\
induzida pela \\
segunda \\
carreira
\end{tabular} & $\begin{array}{l}\text { Modelos } \\
\text { dos novos } \\
\text { referentes } \\
\text { identitários }\end{array}$ & $\begin{array}{c}\text { Tipo de } \\
\text { integração e } \\
\text { de sociabilidade }\end{array}$ \\
\hline $\begin{array}{l}\text { Proximidade } \\
\text { ao combate }\end{array}$ & Organizacional & $\begin{array}{l}\text { Obrigatória } \\
\text { por idade }\end{array}$ & $\begin{array}{l}\text { Positiva } \\
\text { muito forte }\end{array}$ & Negativa & $\begin{array}{l}\text { Nostalgia do } \\
\text { uniforme }\end{array}$ & $\begin{array}{c}\text { Integração } \\
\text { profissional fraca } \\
\text { e sociabilidade } \\
\text { baseada no meio } \\
\text { próximo }\end{array}$ \\
\hline $\begin{array}{l}\text { Técnica } \\
\text { reconvertível }\end{array}$ & Industrial & $\begin{array}{c}\text { Voluntária } \\
\text { após } \\
\text { adquiridas } \\
\text { as condiçõe } \\
\text { s }\end{array}$ & $\begin{array}{l}\text { Positiva } \\
\text { forte }\end{array}$ & $\begin{array}{l}\text { Positiva } \\
\text { muito forte }\end{array}$ & $\begin{array}{l}\text { Mundo do } \\
\text { trabalho civil }\end{array}$ & \begin{tabular}{|} 
Integração \\
profissional forte \\
e sociabilidade \\
baseada em \\
dinâmicas \\
relacionais ricas
\end{tabular} \\
\hline Polivalente & $\begin{array}{c}\text { Tendencionalmen } \\
\text { te mais } \\
\text { organizacional }\end{array}$ & $\begin{array}{l}\text { Induzida } \\
\text { pelas } \\
\text { perspetivas } \\
\text { de carreira }\end{array}$ & Nula & Positiva & $\begin{array}{l}\text { Cristalizada } \\
\text { em torno da } \\
\text { posição } \\
\text { social }\end{array}$ & $\begin{array}{l}\text { Integração } \\
\text { profissional forte } \\
\text { e diversidade de } \\
\text { suportes } \\
\text { relacionais }\end{array}$ \\
\hline Administrativa & $\begin{array}{c}\text { Tendencialmente } \\
\text { mais industrial }\end{array}$ & Voluntária & Positiva & Nula & $\begin{array}{l}\text { Identificação } \\
\text { relativa } \\
\text { às classes } \\
\text { médias }\end{array}$ & \begin{tabular}{|c} 
Integração \\
passiva fundada \\
por uma \\
sociabilidade \\
pouco \\
diversificada
\end{tabular} \\
\hline Polivalente & Organizacional & $\begin{array}{l}\text { Obrigatória } \\
\text { por idade }\end{array}$ & $\begin{array}{l}\text { Positiva } \\
\text { forte }\end{array}$ & - & $\begin{array}{c}\text { Nostalgia } \\
\text { do uniforme, } \\
\text { mas com } \\
\text { o tempo } \\
\text { identificação } \\
\text { com a } \\
\text { pré-reforma }\end{array}$ & $\begin{array}{c}\text { Diversidade } \\
\text { dos suportes } \\
\text { relacionais. } \\
\text { Ligação com } \\
\text { a comunidade } \\
\text { militar }\end{array}$ \\
\hline $\begin{array}{l}\text { Nem muito } \\
\text { técnica, } \\
\text { nem muito } \\
\text { operacional }\end{array}$ & Industrial & $\begin{array}{c}\text { Voluntária } \\
\text { e desejada }\end{array}$ & $\begin{array}{c}\text { Algo } \\
\text { positiva }\end{array}$ & - & $\begin{array}{c}\text { Pré-reforma } \\
\text { nova vaga }\end{array}$ & $\begin{array}{c}\text { Muito boa } \\
\text { integração no } \\
\text { mundo civil e } \\
\text { sociabilidades } \\
\text { fundadas sobre } \\
\text { práticas de lazer }\end{array}$ \\
\hline
\end{tabular}

$\left({ }^{*}\right)$ Os fundamentos de legitimidade de tipo organizacional e de tipo industrial aproximam-se do modelo institucional/ocupacional de Moskos $(1977,1986)$.

Fonte: Adaptado de Duchamp (1990).

Quanto às razões que levam os militares a voluntariamente optar por deixar a carreira militar, há que considerar fundamentalmente o jogo entre a atratividade das oportunidades emergentes na envolvência externa (condicionada pela transferibilidade de competências) e a insatisfação com as circunstâncias internas ao meio militar, sendo que normalmente ocorre um mix de ambos aspetos (Sminchise, 2016). 
Para o caso português, Silva (2017) identifica na atual conjuntura duas ordens de fatores potenciadores de insatisfação entre os militares, a saber: os fatores de contexto de trabalho, como sejam as alterações de estatuto, com impacto nos requisitos para passagem à reserva e reforma, assistência e apoio social; os fatores relacionados com o conteúdo de trabalho, abrangendo as condições remuneratórias, a perda de atratividade e competitividade das carreiras militares, e ainda o que se perceciona como perda de reconhecimento social face ao papel da instituição castrense.

No que se tem vindo a expor denota-se a relevância dos valores militares e das questões identitárias, aspetos que segundo alguns autores têm sido algo negligenciadas, quer quando se considera a motivação para servir, quer enquanto predicadores de eficácia e performance (Johansen, Laberg \& Martinussen, 2014), ou ainda, no que aqui mais nos interessa, quando se trata da propensão para se manterem ou sair das fileiras (Richter, 2017).

Se as razões que levam alguém a escolher uma carreira militar são múltiplas e complexas, o mesmo se pode dizer quando às razões para abandonar as fileiras. Sendo seguro que a saída precoce da carreira das armas é problema comum à generalidade dos Exércitos, parece também consensual que uma retenção de $100 \%$ não é possível, nem desejável (Sminchise, 2016).

\section{Processos de transição para a reserva e reforma dos militares do Exército Português}

\section{Caraterização sociográfica}

Em Portugal, a reforma estrutural designada de Defesa 2020, cuja génese esteve associada à conjuntura desfavorável dos últimos anos e à necessidade de implementar medidas reformistas, define "um novo modelo para a Defesa Nacional e que estabelece umas FFAA mais modernas, mais operacionais e sustentáveis, integradas num edifício conceptual e legislativo coerente e organizado, com os seus recursos optimizados e com um claro aumento de eficiência das estruturas" (MDN, 2015, p. 5).

Daí decorre o planeamento de despesas com pessoal e a consequente fixação de efetivos militares, que em termos globais para os três Ramos foram redimensionados entre 30.000 e 32.000 militares, incluindo os que estão na reserva na efetividade de serviço. Em complemento, visa a compatibilização das necessidades de serviço efetivo com o fluxo normal das carreiras, tendo tido implicações na revisão do EMFAR. 
Alterações que se repercutiram na capacidade de recrutamento e manutenção de pessoal nas FFAA e no Exército português em particular, cujos efetivos se situam em valores ainda abaixo do previsto no Decreto-Lei $n^{\circ}$ 84/2016, de 21 de dezembro.

Face a este contexto de mudança, e com vista à análise das suas principais implicações na passagem para a reserva e reforma dos militares do Exército português, estabeleceu-se como período de análise o ano 2000 e seguintes.

Do universo de 4872 militares que transitaram para as situações de reserva ou de reforma durante o período em análise, a quase totalidade são homens, um reflexo dos condicionalismos inerentes à presença das mulheres nas FFAA, que vale a pena passar em revista.

Tradicionalmente considerada uma instituição masculina, as FFAA têm vindo a registar uma participação crescente das mulheres na vida militar nas últimas três décadas, o que releva o interesse de se discutir sobre as suas funções militares, tal como Mady Segal (1999) propõe na teoria dos fatores que influenciam a participação militar das mulheres, quanto ao grau de representatividade e natureza das atividades. Trilogia de fatores de natureza militar, estrutura social e cultura que permite indicar que o fator mais importante no envolvimento das mulheres na vida militar são as necessidades de pessoal militar, enquanto para a permanência das mulheres, quando o país está em paz, o maior contributo explicativo recai sobre os valores culturais que promovem a igualdade de género. Para H. Carreiras,

embora exista uma diversidade de variáveis que pode explicar a ausência ou diminuta percentagem de mulheres nas áreas operacionais e em combate, incluindo a sua própria disponibilidade, boa parte dos obstáculos que persistem ao nível institucional remetem para o plano dos valores culturais sobre a 'natureza' e os papeis sociais de homens e mulheres, refletindo-se claramente no debate sobre a participação militar feminina e a eficácia militar (Carreiras, 2013, p. 480).

No caso português, e para Alves (1999), a participação das mulheres na vida militar remonta à I Guerra Mundial com o envio para França de 10 voluntárias, alferes com curso de primeiros socorros, integradas no Corpo Expedicionário Português. Presença feminina que voltou a destacar-se em 1961, quando se criou o quadro das enfermeiras para-quedistas da Força Aérea Portuguesa.

Esta participação das mulheres portuguesas no serviço de saúde, e excecionalmente em algumas atividades militares no passado, foi alterada com a nova Lei doServiço Militar (Lei $n^{\circ}$ 22/91) que determinou a integração das mulheres na instituição militar em tempo de paz, em regime de voluntariado e contrato. A mesma lei também criou, a partir de 1992, as condições legais de acesso das mulheres aos Quadros 


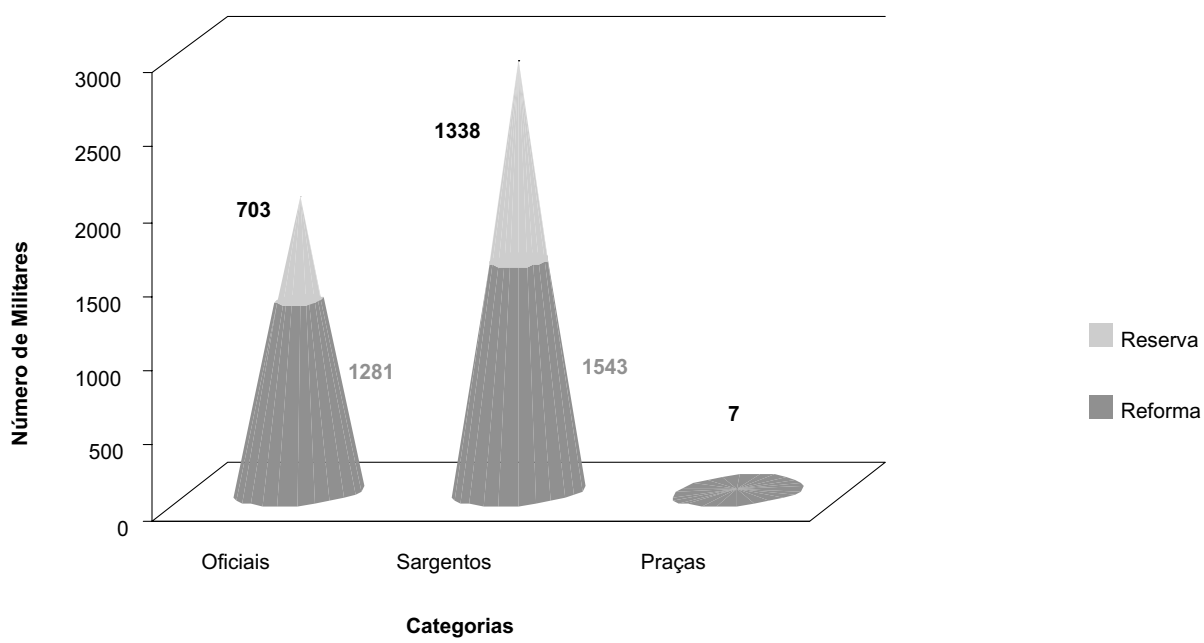

Figura 2 Situação de reserva/reforma dos militares, por categoria (2000-2016) Fonte: Direção de Administração de Recursos Humanos do Exército.

Permanentes, ao final dos seus cursos nas Escolas de Formação de Oficiais e Sargentos (Romão \& Baltazar, 2015).

Circunstâncias que justificam que no universo em estudo, de um total de 4872 militares, apenas se encontram 14 mulheres, em situação de reserva (6) e de reforma (8).

Do conjunto destas militares, só 2 pertencem à categoria de Sargentos ( $1^{\circ}$ Sargento), enquanto as oficiais se distribuem pelos seguintes postos: 5 Tenentes-Coronéis, 4 Capitães, 2 Majores e 1 Coronel. Por armas e serviços, pertencem maioritariamente à área da saúde (11 do total das 14), e nestas encontram-se 2 enfermeiras para-quedistas reformadas com incorporação militar no início da década de 70. Há ainda uma Capitã de Artilharia, outra pertencente aos Quadros Técnicos e uma $1^{\circ}$ Sargento de Administração Militar. Distribuição que revela a predominância de atividades não operacionais. Acrescente-se ainda que as que não são da área de saúde integraram o Exército português entre 1993 a 1996, ao abrigo da nova Lei do Serviço Militar (Lei n 22/91). Dos motivos de transição para a reforma e reserva, destaque-se que 5 militares passaram diretamente para a reforma por motivos de saúde, as restantes 7 solicitaram a passagem à reserva mediante requerimento, e ocupam postos próximos do fim da carreira militar (1 Coronel e 5 Tenente-Coronel).

Retomando a perspetiva de análise do total dos militares, o peso dos que se encontram na reserva e na reforma é de, respetivamente $41,9 \%$ e $58,1 \%$. A sua distribuição por categoria corresponde ao que se observa na figura 2. 


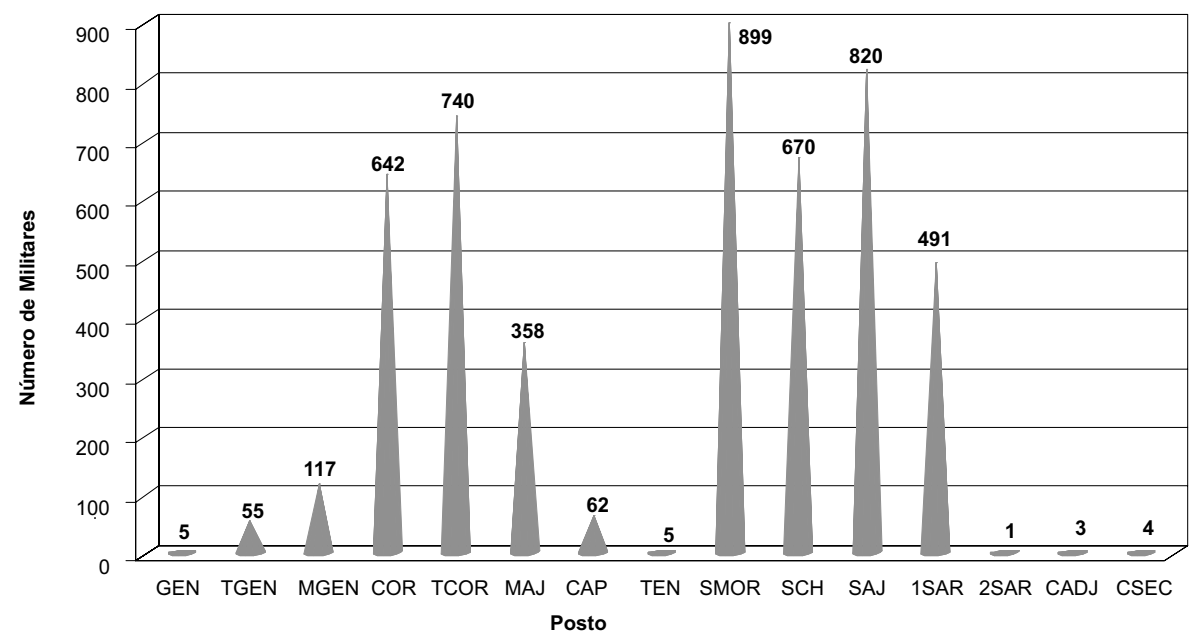

Figura 3 Situação de reserva/reforma dos militares, por postos (2000-2016)

Fonte: Direção de Administração de Recursos Humanos do Exército.

Nesta distribuição predominam os Sargentos (59,1\%), enquanto os Oficiais correspondem a 40,7 \%, e 7 dos militares em situação de reserva e reforma são Praças. Situação que remete para uma abordagem mais detalhada sobre o perfil destes 7 militares, uma vez que correspondem na base de dados em análise a um quadro entretanto extinto. São militares incorporados entre 1965 e 1981, todos em situação de reforma e distribuídos pelos postos de Cabo-de-secção e Cabo-adjunto. O Decreto-Lei 123/87, de 17 de março, criou o quadro permanente das praças do Exército, "considerando que a transitoriedade, nas fileiras do Exército, de praças em serviço normal e na situação de contratadas não satisfaz cabalmente todas as necessidades funcionais orgânicas e, particularmente, em especialidades de formação mais complexa ou mais sensível". E de acordo com o art. $15^{\circ}$, refere-se à possibilidade destas praças do QP integrarem os quadros de oficiais ou de sargentos, conforme as condições expressas nos diplomas legais estabelecidos para o efeito. $\mathrm{O}$ que lhes conferia a oportunidade de progressão na carreira militar no QP subindo à categoria de Sargento ou Oficial.

Esta circunstância justifica, em parte, o número residual de praças em situação de reforma a 31 dezembro de 2016, porém importa assumir como determinante a extinção progressiva deste Quadro logo em 1990 (cf. Decreto-Lei 34/ A/90 de 24 de janeiro), por cancelamento de admissões. Extinção que foi concluída com a passagem à reserva dos últimos militares do QPPE - Quadro Permanente de Praças do Exército, de acordo com a lista de antiguidades de praças em julho de 2011. 
Para o universo de militares do Exército português na reserva e reforma, no período em análise, e dando continuidade à sua sociografia, destaca-se agora a sua distribuição por postos por se considerar que esta variável contribui para a discussão sobre a tão almejada progressão na carreira militar e a existência de contrariedades que tendem a limitar a plena concretização das expetativas destes profissionais.

Pela observação da figura 3 , verifica-se que no que concerne aos efetivos militares do QP por postos, mais de $3 / 4$ dos militares em situação de reserva/reforma são Sargento-Mor (18,5\%), Sargento-Ajudante (16,8\%), Tenente-Coronel (15,2\%), Sargento-Chefe $(13,8 \%)$ e Coronel $(13,2 \%)$. Para a categoria de Sargentos, observa-se que o posto em final de carreira - Sargento-Mor - é o que concentra maior número de militares na reserva e reformados. Ou seja, para estes militares o tempo de serviço termina quando conseguem alcançar o topo da sua carreira profissional, enquanto na categoria de Oficiais é o posto de Tenente-Coronel que concentra um maior número de militares em situação de reserva e reforma. Para os Oficiais, a situação de reserva e reforma recai quase na sua totalidade em postos relativos a Oficiais Superiores, e os postos que correspondem ao Corpo de Oficiais Generais representam $3,6 \%$ do total do universo em estudo. Por sua vez se forem destacados os postos de Coronel e de Tenente-Coronel, verifica-se que do total de oficiais na reserva e reforma estes ocupam $70 \%$, postos do topo da carreira de Oficiais Superiores.

Considera-se que no estudo das carreiras militares e reconfigurações de percursos de vida dos militares após términus do tempo de serviço, a distribuição do universo em estudo por armas e serviços assume particular interesse no contexto da presente abordagem. Para o efeito, e face à grande diversidade de armas e serviços, procedeu-se a uma categorização por áreas que teve como critério base a maior similitude entre armas e serviços, como se passa a indicar:

1. Saúde: Medicina; Serviço de Saúde; Medicina Dentária; Farmácia; Medicina Veterinária; e Técnicos de Enfermagem, Diagnóstico e Terapêutica;

2. Engenharias: Engenharia; Transmissões; e Material;

3. Operacionais: Artilharia; Cavalaria e Infantaria;

4. Administração: Administração Militar; Serviço de Administração;

5. Corpo de Oficiais Generais;

6. Serviços Técnicos (de Oficiais): Técnicos de Exploração de Transmissões; Técnicos de Manutenção de Transmissões; Técnicos de Manutenção de Material; Técnicos de Pessoal e Secretariado; Técnicos de Transportes; e Transportes;

7. Quadros Especiais: Quadro Especial de Oficiais; Quadro Técnico de Secretariado; Quadro Apoio de Secretariado; e Serviço Postal Milita;

8. Serviço Geral do Exército; 


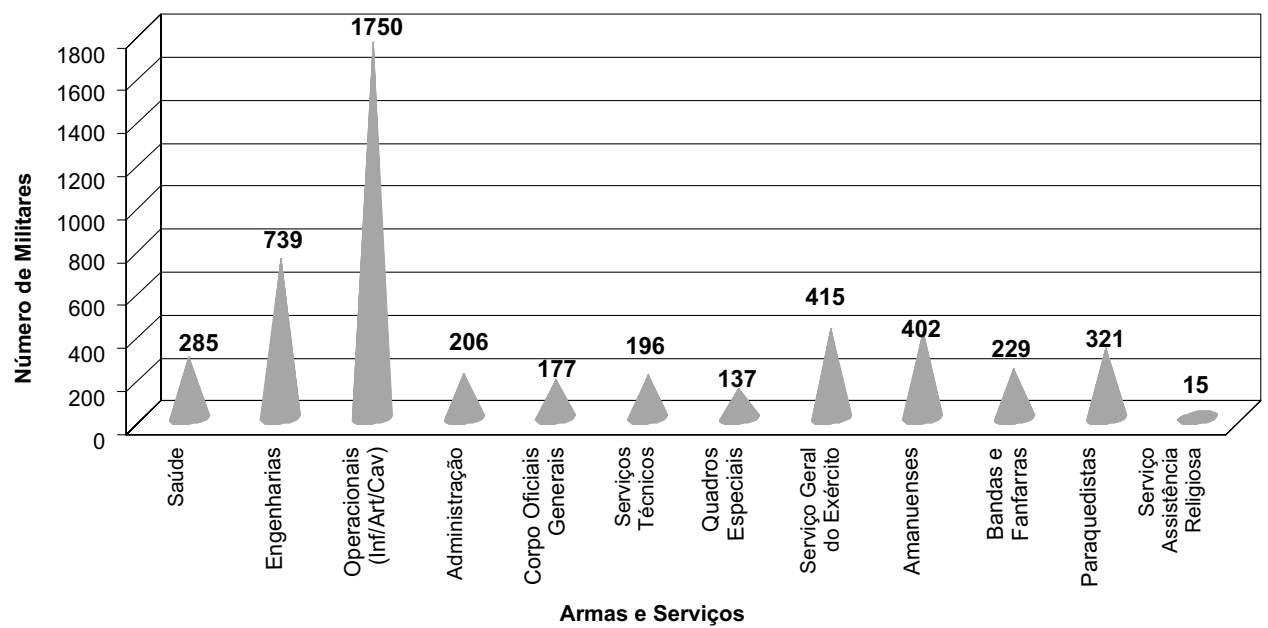

Figura 4 Situação de reserva/reforma dos militares, por armas e serviços (2000-2016)

Fonte: Direção de Administração de Recursos Humanos do Exército.

\section{Quadro de Amanuenses;}

10. Bandas e Fanfarras: Chefes de Bandas de Música; Corneteiros e Clarins; e Músicos;

11. Paraquedistas: Paraquedistas; Enfermeiros Paraquedistas; Serviço Geral de Paraquedistas; Amanuenses e Paraquedistas;

12. Serviço de Assistência Religiosa: Serviço de Apoio Religioso.

As áreas resultantes do referido processo de categorização estão representadas na figura 4. Representação gráfica que destaca o número de militares das armas de infantaria, artilharia e cavalaria (operacionais), seguindo-se os militares de engenharia. A área dos operacionais destaca-se em muito das restantes (35,9\%), seguida da Engenharia $(15,2 \%$,$) . Verifica-se ainda a presença de dois quadros com extinção$ progressiva que são o Serviço Especial do Exército (8,5\%) e os Amanuenses (8,3\%).

As demais armas e serviços apresentam um número muito inferior de militares na situação de reserva e de reforma.

Para concluir a sociografia referente ao universo em estudo, considera-se oportuno perceber qual é a idade média de passagem à reserva, por categorias. Isto é, conforme a figura 5, são os oficiais que permanecem mais tempo ao serviço da instituição militar (52 anos), enquanto os Sargentos e Praças apresentam uma idade média de 50 anos.

Por estarmos perante uma medida de tendência central - idade média considerou-se oportuno identificar para cada uma das categorias de militares os 


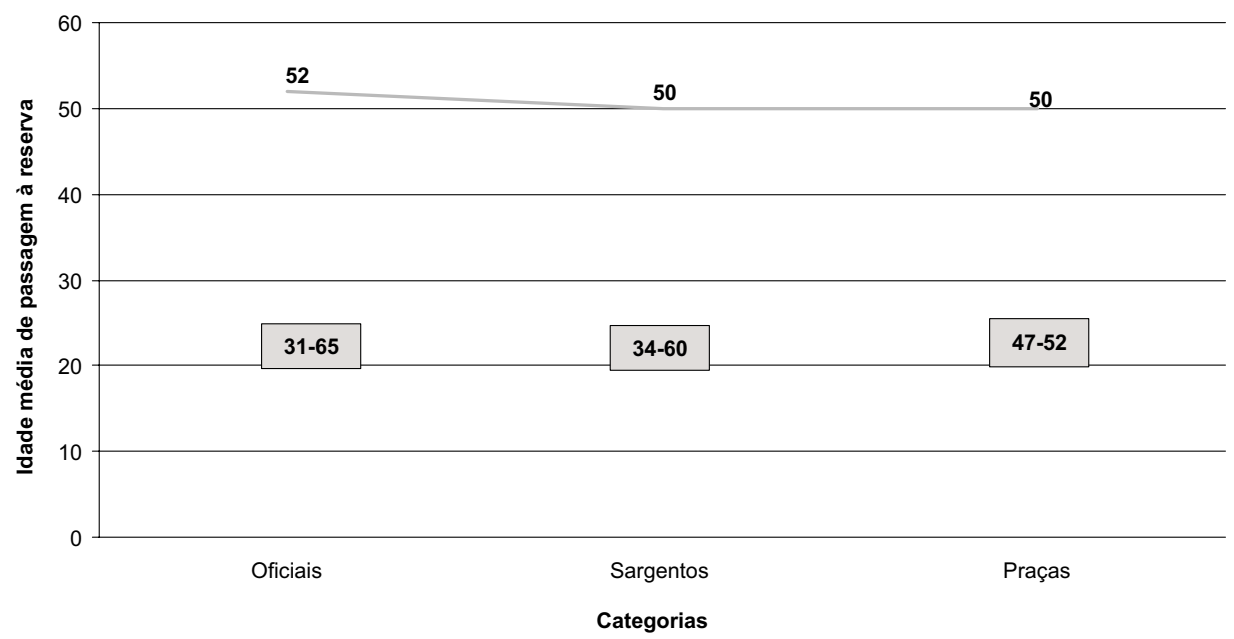

Figura 5 Idade média de passagem à reserva dos militares, por categorias (2000-2016)

Fonte: Direção de Administração de Recursos Humanos do Exército.

limites inferiores e superiores da idade de passagem à reserva. Eé nesta perspetiva que se conclui que são as Praças que apresentam maior convergência entre limite inferior e superior, ou seja, o mais novo a sair do ativo tinha 47 anos enquanto no limite oposto a Praça que permaneceu mais tempo na carreira militar foi até à idade de 52 anos. Situação que está relacionada com a especificidade de extinção deste quadro e a possibilidade de progressão de carreira destes militares com a passagem às categorias de Oficiais e Sargentos.

No caso da categoria dos Sargentos, os limites situam-se entre os 34 e 60 anos, enquanto para os Oficiais o intervalo de idades é maior, apresentando uma idade inferior de apenas 31 anos e o limite superior é de 65 anos. Situação que é determinada pelas armas e serviços, assim como os quadros especiais que integram a categoria dos Oficiais. Naturalmente, os militares do Corpo de Oficiais Generais permanecem até mais tarde na carreira, enquanto os militares em áreas profissionais com maior proximidade funcional às civis tendem a sair das fileiras em idades mais precoces.

Ritmos de passagem para a reserva e reforma

Com a reestruturação das FFAA, e mais recentemente no âmbito do projeto estratégico "Defesa 2020", têm sido introduzidas várias alterações ao EMFAR, destacando-se a introdução de condições mais restritivas nos processos de transição para as 
Tabela 2 Síntese das condições de passagem à situação de reserva definidas pelos EMFAR 1999, 2003 e 2015

\begin{tabular}{|c|c|c|}
\hline $\begin{array}{l}\text { EMFAR } 1999 \\
\text { (Decreto-Lei n. } 236 / 99 \\
\text { de } 25 \text { de Junho) }\end{array}$ & $\begin{array}{c}\text { EMFAR } 2003 \\
\text { (Decreto-Lei } \mathrm{n}^{\circ} 197-\mathrm{A} / 2003 \\
\text { de } 30 \text { de agosto (com as alterações } \\
\text { introduzidas pelo } \mathrm{DL} \mathrm{n}^{\circ} 166 / 2005 \\
\text { de } 23 \text { de setembro) }\end{array}$ & $\begin{array}{c}\text { EMFAR } 2015 \\
\text { (Decreto-Lei n90/2015 } \\
\text { de } 29 \text { de maio) }\end{array}$ \\
\hline $\begin{array}{l}\text { Artigo } 153^{\circ} \text { condições } \\
\text { de passagem à reserva }\end{array}$ & $\begin{array}{l}\text { Artigo } 152^{\circ} \text { condições } \\
\text { de passagem à reserva }\end{array}$ & $\begin{array}{l}\text { Artigo } 153^{\circ} \text { condições de } \\
\text { passagem à reserva }\end{array}$ \\
\hline $\begin{array}{c}\text { Atinja o limite de idade estabelecido } \\
\text { para o respetivo posto. }\end{array}$ & $\begin{array}{c}\text { Atinja o limite de idade estabelecido } \\
\text { para o respetivo posto. }\end{array}$ & $\begin{array}{c}\text { Atinja o limite de idade previsto para } \\
\text { o respetivo posto. }\end{array}$ \\
\hline $\begin{array}{c}\text { Tenha } 20 \text { ou mais anos de serviço } \\
\text { militar, a requeira e Ihe seja } \\
\text { deferida. }\end{array}$ & $\begin{array}{c}\text { Tenha } 20 \text { ou mais anos de serviço } \\
\text { militar, a requeira e lhe seja } \\
\text { deferida. }\end{array}$ & $\begin{array}{l}\text { Complete o tempo máximo de } \\
\text { permanência na subcategoria ou no } \\
\text { posto. }\end{array}$ \\
\hline $\begin{array}{l}\text { Declare, por escrito, desejar a } \\
\text { passagem à reserva depois de } \\
\text { completar } 36 \text { anos de tempo de } \\
\text { serviço militar ou } 55 \text { anos de idade. }\end{array}$ & $\begin{array}{l}\text { Declare, por escrito, desejar passar } \\
\text { à reserva depois de completar } 36 \\
\text { anos de tempo de serviço militar e } \\
55 \text { anos de idade. }\end{array}$ & $\begin{array}{c}\text { Declare, por escrito, desejar passar } \\
\text { à reserva depois de completar } 40 \\
\text { anos de tempo de serviço militar e } \\
55 \text { anos de idade. }\end{array}$ \\
\hline $\begin{array}{c}\text { Seja abrangido por outras condições } \\
\text { previstas neste Estatuto. }\end{array}$ & $\begin{array}{c}\text { Seja abrangido por outras condições } \\
\text { legalmente previstas. } \\
\text { Na situação de passagem à reserva } \\
\text { prevista no } \mathrm{n}^{\circ} 7 \text { do artigo } 31^{\circ}-\mathrm{F} \text { da } \\
\text { LDNFA }\left(^{*}\right) \text {, a indemnização a } \\
\text { prestar pelo militar é fixada pelo } \\
\text { CEM do ramo respetivo, nos termos } \\
\text { constantes do } n^{\circ} 3 \text { do artigo } 170^{\circ} \text { do } \\
\text { presente Estatuto. }\end{array}$ & $\begin{array}{c}\text { Seja abrangido por outras condições } \\
\text { legalmente previstas. }\end{array}$ \\
\hline
\end{tabular}

$\left(^{*}\right)$ LDNFA — Lei de Defesa Nacional e das Forças Armadas.

Fonte: EMFAR (1999, 2003, 2015).

situações de reserva e de reforma. Com vista a uma sistematização das condições de passagem à reserva, passa-se a apresentar uma síntese comparativa dos últimos EMFAR, como mostra a tabela 2.

Partindo do pressuposto que os militares, no intuito de se acautelarem face às consequências da mudança no quadro legislativo, anteciparam a passagem à reserva, procedeu-se à representação no gráfico 5 do número de militares que passaram pela reserva/reformados no período compreendido entre $2000 \mathrm{e}$ 2016. E é possível verificar que a repercussão das alterações legislativas se tem feito sentir em picos de passagem à situação de reserva, v. g., a entrada em vigor de cada alteração legal é concomitante com a saída de militares profissionais para a reserva.

Em 2005, foram 642 os militares que passaram à reserva, momento de significativas alterações definidas no EMFAR à época, e que passados 5 anos se repercutiu num aumento expressivo de militares que passaram à reforma (limite de anos em situação de reserva, exceção para os militares que ficam em efetividade de serviço). Situação 


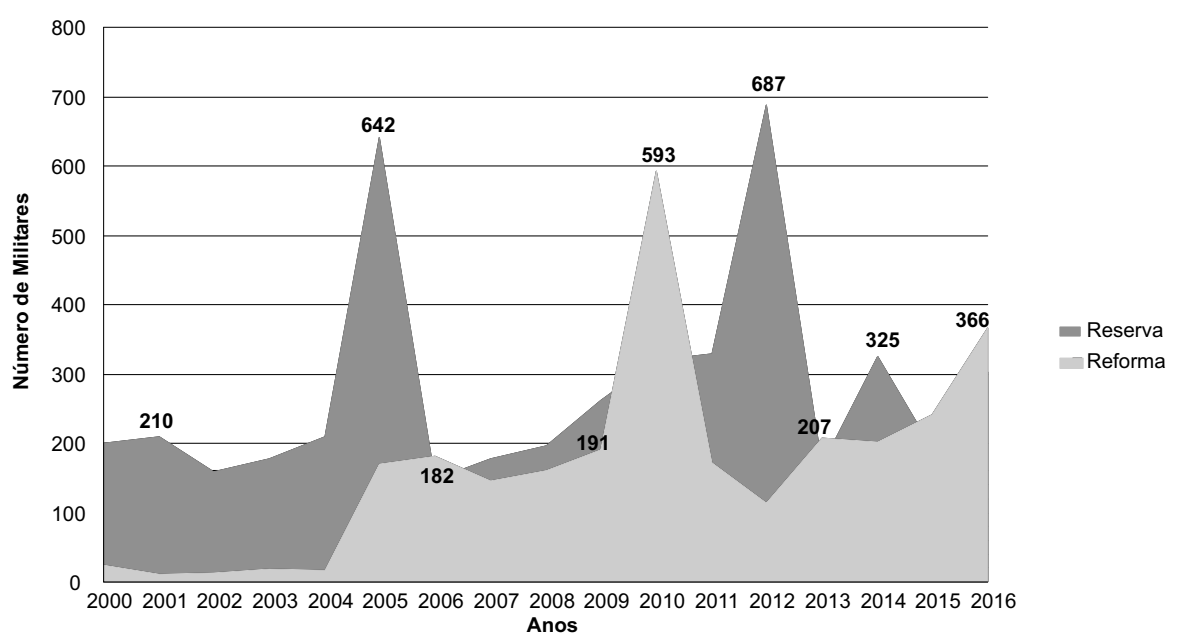

Figura 6 Militares que passaram pela reserva/reformados, por anos (2000-2016)

Fonte: Direção de Administração de Recursos Humanos do Exército.

análoga verificou-se em 2012, com uma cifra que até supera mesmo o número de militares com passagem à reserva em 2005, pelo que em 2017 se voltará a verificar um novo pico de saída de militares para a reforma.

Um dado relevante é que a saída para a reserva é transversal e segue a mesma linha na categoria de Oficiais e na categoria de Sargentos. Verificamos que em 2005 os militares obstaram às medidas penalizadoras do Decreto-Lei nº197-A/2003 de 30 de agosto (com as alterações introduzidas pelo Decreto-Lei n ${ }^{\circ} 166 / 2005$ de 23 de setembro) optando pela passagem à reserva ao abrigo das condições do EMFAR de 1999 (Decreto-Lei n. ${ }^{\circ}$ 236/99 de 25 de junho), apesar de ter sido criado um regime de salvaguarda para que o regime consagrado no decreto-lei não prejudicasse a passagem à situação de reserva ou de reforma dos militares que preenchiam as condições para tal até 31 de dezembro de 2005, independentemente da data em que a requeressem. No entanto, o texto legal não é clarificador, pois apesar de não colocar em causa a passagem à reserva ou reforma para esses militares, não define as condições em que essa transição é feita e quais as regras que se aplicam, nomeadamente ao nível do cálculo da pensão de reforma, dando assim lugar a interpretações distorcidas e equívocos que o legislador não obstou.

Os efeitos da suspensão do EMFAR em 2005 no que toca às condições de passagem à reserva, inibindo de o fazer todos aqueles que até 31 de dezembro de 2012 não tivessem completado 39 anos de tempo de serviço ou 53 anos de idade fizeram-se sentir neste ano até ao último mês. Recorda-se que até 2005 era de 36 anos de 
tempo de serviço ou 55 anos de idade. Com a lei do orçamento de estado de 2013 passou para 36 anos de tempo de serviço militar e 55 anos de idade.

Em 2015, no EMFAR agregaram-se e consagraram-se um conjunto de medidas penalizadoras para os militares, entre as quais se destacam as seguintes determinações estatutárias: aumento do tempo mínimo de permanência nos postos; as condições de passagem à reserva; a alteração das regras de promoção na situação de adido (apenas após um ano no cargo); deixa de estar na situação de adido o militar em qualquer estrutura que integre o Estado-Maior-General das Forças Armadas (EMGFA); aumento dos limites de idade para a passagem à reserva; tempos longos de permanência nos postos cimeiros da hierarquia, na categoria de oficiais e na categoria de sargentos. A estas medidas há que associar a redução de efetivos interligada, por sua vez, à alteração da estrutura orgânica das FFAA, situação que conduz a prazo à estagnação das carreiras. Alvitra-se a permanência prolongada nos postos mais baixos para a generalidade dos militares profissionais.

A retenção dos militares no Exército português revela-se como um dos grandes desafios que se colocam à instituição militar, o que justifica desde logo uma análise mais detalhada sobre o tempo de permanência na carreira dos militares na reserva e reforma. Tempo de serviço que é diverso quando se analisam as armas e serviços dos militares na reserva e reforma.

Diferentes tempos de permanência na carreira militar remetem para o interesse de se determinar o tipo de associação por armas e serviços, mas em paralelo indagar acerca dos motivos da passagem à reserva dos militares do Exército português.

Decorrente do anteriormente exposto, as alterações do quadro legislativo no período em análise têm correspondido, de grosso modo, à introdução de condições mais restritivas nos processos de transição para as situações de reserva e de reforma, e que os militares tendem a antecipar. Não obstante esta configuração da tendência evolutiva da legislação desde a anterior década, a diversidade dos motivos a que os militares podem recorrer para deixarem a sua situação de ativo corresponde a três tipos: requerimento, declaração e imposição.

Do universo em estudo, apenas 3,4\% (167 militares) entraram na reforma sem que antes tivessem passado pela situação de reserva, o que significa que na generalidade dos percursos a reforma é antecedida por um período de transição, que nalguns casos poderá configurar uma pré-reforma.

Quanto aos motivos subjacentes à entrada na reserva, verifica-se que 16,3\% fizeram-no por imposição institucional. O que remete para a constatação de que $83,6 \%$ dos militares, no periodo de 2000 a 2016, tomaram a decisão de alterar a sua situação profissional, requerendo a sua passagem à reserva $(48 \%)$ ou 


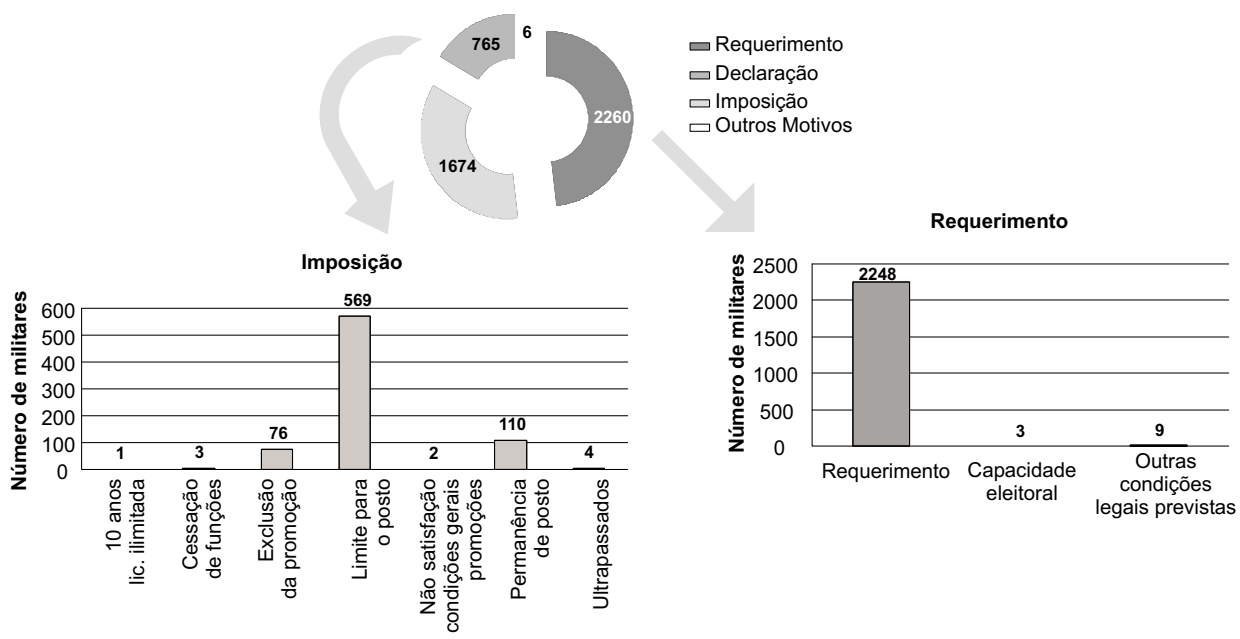

Figura 7 Motivos de passagem à reserva dos militares (2000-2016)

Fonte: Direção de Administração de Recursos Humanos do Exército.

tendo declarado a sua vontade $(35,6 \%)$ em deixar a situação de militar no ativo. O que quer significar que só menos de $1 / 6$ dos militares sairam do Exército por imperativo da organização militar, e que a sua passagem à reserva é pela esmagadora maioria dos casos uma opção do próprio militar, como se pode observar através da figura 7.

No que concerne aos motivos que determinaram uma reserva por imposição institucional a 765 dos militares, importa destacar o facto de 74,4 \% do total destes militares terem terminado a sua carreira militar por limite de idade estabelecido para o respetivo posto; $14,3 \%$ por limite de tempo de permanência no posto e $9,9 \%$ por exclusão de promoção ao posto imediato. Motivações que se prendem com questões de gestão da carreira profissional (modelo up-or-out), e que remetem para uma análise mais detalhada por categorias e postos, nomeadamente para as situações de passagem à reserva por limite de idade no posto.

Dos militares que saíram por limite de idade no posto, $76,8 \%$ são Oficiais e apenas $23,2 \%$ pertencem à categoria de Sargentos.

No que concerne à análise da sua distribuição por postos observa-se que na categoria de Oficiais, 45,8\% são Coronéis, 25,4\% Oficiais Generais (MGen e TGen), 15,6\% Tenentes-coronéis, 9,8\% Majores e os restantes são Capitães. Já para a categoria dos Sargentos, a saída por limite de idade no posto ocorreu em 43,2\% dos casos no posto de $1^{\circ}$ Sargento, seguindo-se $31,8 \%$ para os Sargentos-ajudantes, $12,9 \%$ em Sargento-mor e 12,1\% em Sargento-chefe. 
E porque o EMFAR possibilita que o militar solicite, através de declaração escrita, a sua passagem à reserva "depois de completar 40 anos $^{1}$ de tempo de serviço militar e 55 anos de idade" (alínea c) do ${ }^{\circ} 1$ do artigo $153^{\circ}$ ) do DL no 90/2015), no período em análise 35,6\% militares do Exército português passaram à reserva por este motivo, e de uma forma transversal nas categorias de oficiais e de sargentos.

De referir que destes, 3,8 \% passaram à reserva já ao abrigo do novo EMFAR (alínea c) do artigo 153) nos anos de 2015 e 2016, e que ao abrigo das disposições transitórias mantinham-se os regimes de passagem à reserva e reforma, salvaguardando-se as condições previstas no art. $3^{\circ}$ do DL n ${ }^{\circ}$ 166/2005.

Mas é no contexto do EMFAR de 2003, conjuntamente com o art.3 do DL $\mathrm{n}^{\circ} 166 / 2005$, que $75 \%$ dos militares passam à situação de reserva, facto que poderá corresponder a uma opção individual antevendo as alterações, de caracter mais restritivo, que iriam corresponder ao novo articulado legal sobre as condições de passagem à reserva.

Por seu turno, e cf. se observa no gráfico 6, quase metade do universo em estudo (48\%), requereu a passagem à reserva, por ter 20 ou mais anos de serviço militar (cf. EMFAR 1999 e 2003). Podem ainda requerer o fim da carreira ao abrigo de outras condições legalmente previstas, como seja para participação política passiva / capacidade eleitoral ( $\mathrm{n}^{\circ} 10$ do artigo 31 do DL $\left.n^{\circ} 29 / 1982\right)$, embora estas situações sejam muito residuais, encontrando-se apenas um total de 12 militares.

No que concerne aos militares em situação de reforma, que correspondem a $58,1 \%$ do universo em estudo, apresentam como principal motivo de passagem a esta situação terem estado 5 anos na reserva fora da efetividade de serviço, apesar do limite de idade (60, 65 e 66 anos) assim como as situações de Deficientes das Forças Armadas e de Junta Hospitalar de Inspeção se apresentarem como razões de passagem à reforma.

\section{Conclusões}

A retenção de profissionais qualificados, e sobretudo o abandono precoce da carreira militar, constitui um problema que afeta a generalidade das instituições militares e como tal vem merecendo reflexão nos contextos nacionais e inclusivamente ao nível da NATO.

Neste artigo abordaram-se os processos de termo da carreira por via da transição para as situações de reserva e de reforma no Exército português. No universo em estudo (4872 militares do Quadro Permanente do Exército) verifica-se que a transição para a reserva é maioritariamente uma opção do militar. As saídas por 
imposição estatutária não chegam a abranger $17 \%$. O ingresso na reserva ocorre em média por volta dos 50 anos de idade no caso dos Sargentos e 52 anos no caso dos Oficiais. Idades de cessação da carreira com algum diferencial consoante as Armas/serviços, evidenciando-se uma tendência para saídas mais precoces nos militares oriundos de Armas/serviços com mais equivalência funcional no mundo de trabalho civil, aspeto consonante com o que outros estudos vêm evidenciando (por exemplo, Duchamp, 1990; Sminchise, 2016; Wilmoth \& London, 2003).

Transversal às diferentes categorias e armas/serviços é o facto da esmagadora maioria dos militares reformados ter passado pela reserva, o que acrescenta interesse em conhecer detalhadamente as lógicas e os impactos em termos organizacionais e individuais, sobretudo se considerarmos o problema de retenção de efetivos que atualmente se coloca nas FFAA em geral e no Exército em particular.

A reserva e a reforma cumprem importantes funções inexoravelmente relacionadas com a condição militar. Por um lado, fazem parte do sistema de compensações e, nessa medida, integram os direitos e as expectativas inerentes ao horizonte da duração da carreira militar. Por outro lado, atuam como mecanismos reguladores da carreira, designadamente ao abrirem possibilidades de promoção para os mais jovens. Alterações nas condições de acesso a essas formas de mobilidade causam impacto nas opções de permanecer ou sair da carreira. Como se viu, entre 2000 e 2016, observam-se picos de intensidade na passagem à reserva (e depois na passagem à reforma) coincidentes com as alterações no Estatuto Militar.

A análise das alterações legislativas permitiu compreender o sentido das mudanças introduzidas que, no essencial, tornam mais rígida e restritiva a mobilidade entre a atividade/reserva/reforma, programando a carreira para um horizonte de 40 anos. Se, por um lado, tais mudanças representam necessidades de resposta do sistema em termos de retenção dos Recursos Humanos qualificados e de adaptação ao regime geral de aposentação (no caso da reforma); por outro lado, ao implicarem mais limitações no sistema de recompensas podem induzir insatisfação. Ora, de entre as vicissitudes e constrangimentos que podem impulsionar os militares a requerer a saída antes do limite de idade, uma evolução desfavorável no sistema de pensões, salários considerados baixos, uma colocação não desejada, ausência de perspetivas de carreira ou ainda o receio de alterações no âmbito da defesa estão normalmente entre as razões evocadas (Bailleul-Hugele et al. 2008; Duchamp, 1990; McNeill, Lecca \& Wright, 1983; Sminchise, 2016; Spiegel \& Shultz, 2003).

Importa então considerar os processos no duplo impacto, em termos organizacionais e em termos da expetativa dos militares e respetiva motivação quanto ao momento de cessar a carreira. 
Neste artigo fez-se uma análise descritiva dos processos de mobilidade para a reserva e reforma, abarcando diferentes coortes geracionais que consequentemente prestaram serviço em contextos institucionais diferenciados, incluindo os que participaram na Guerra de África. Conhecer a diversidade de motivações, os respetivos percursos e trajetórias, as reconfigurações dos modos de vida decorrentes do abandono do uniforme e regresso à vida civil fazem parte dos objetivos a alcançar nas fases seguintes do projeto C-MILR3.

\section{Notas}

Por decisão pessoal, os autores do texto escrevem segundo o novo acordo ortográfico.

1 Condição de passagem à reserva que no EMFAR de 1999 e de 2003 correspondia a 35 anos de TSM e/ou 55 anos, respetivamente.

\section{Agradecimentos}

O presente artigo apresenta dados preliminares do Projeto de Investigação C_MILR3, a decorrer no Centro de Investigação da Academia Militar (CINAMIL). Os autores agradecem o apoio do CINAMIL, bem como do Exército português e, em particular agradecem à Direção de Administração dos Recursos Humanos do Exército, pela cedência de dados.

\section{Referências}

Alves, J. H. E. (1999). A mulher e as Forças Armadas Portuguesas. Nação e Defesa, 88, 71- 80.

Asch, B. J., \& Warner, J. T. (1994). A theory of military compensation and personnel policy. Santa Monica, California: Rand.

Baltazar, M. S. (2005). As Forças Armadas Portuguesas. Desafios numa sociedade em mudança. Lisboa: Caleidoscópio.

Bellino, R. (1969). Psychosomatic problems of military retirement. Psychosomatics, 10(5), 318-321.

Bellino, R. (1970). Perspectives of military and civilian retirement. Mental Hygiene, 54(4), $580-583$.

Caforio, G. (1988). The military profession: Theories of change. Armed Forces and Society, 15(1), 55-69.

Caplow, T., \& Vennesson, P. (2000). Sociologie militaire. Paris: Armand Colin

Carreiras, H. (2013). Mulheres, direitos e eficácia militar: O estado do debate. Revista Militar, (2536), 477-495. 
Carrilho, M. (1978). Principais tendências na sociologia militar - Literatura e selecção bibliográfica. Nação e Defesa, 7, 157-169.

Creswell, J. (2014). Research design - Qualitative, quantitative and mixed methods approaches. Los Angels: Sage Publications.

Decreto-Lei no 22/1991 (1991). Lei de alteração à Lei do serviço Militar (Lei n. ${ }^{\circ}$ 30/87, de 7 de julho). Diário da República I-A Série. No 138/1991 (1991-06-19), 3170-3173.

Decreto-Lei n. ${ }^{0}$ 34-A/1990 (1990). Aprova o estatuto dos militares das Forças Armadas. Diário da República Série I. No 243/2016 (1990-01-24), 342-(2)-342-(61).

Decreto-Lei n. ${ }^{\circ}$ 84/2016 (2016). Fixa os efetivos das Forças Armadas, em todas as situações, para o ano de 2017. Diário da República Série I. No 243/2016 (2016-12-21), 4771-4773.

Decreto-Lei n. ${ }^{\circ}$ 90/2015 (2015). Aprova o estatuto dos militares das Forças Armadas. Diário da República Série I. No 104/2015 (2015-05-29), 3198-3253.

Decreto-Lei n. ${ }^{\circ}$ 123/1987 (1987). Cria o quadro permanente das praças do Exército. Diário da República Série I. No 243/2016 (1987-03-17), 1042-1044.

Decreto-Lei n. ${ }^{\circ}$ 166/2005 (2005). Altera o Decreto-Lei n. ${ }^{\circ}$ 236/99, de 25 de junho, que aprova o Estatuto dos Militares das Forças Armadas, modificando o regime da passagem à reserva e à reforma dos militares das Forças Armadas. Diário da República Série I. No 184/2005 (2005-09-23), 5692-5694.

Decreto-Lei n. ${ }^{\circ}$ 197-A/2003 (2003). Altera o Decreto-Lei n. ${ }^{\circ}$ 236/99, de 25 de junho, que aprova o Estatuto dos Militares das Forças Armadas (EMFAR), e revoga os artigos $3 .^{\circ}, 5^{\circ}{ }^{\circ}$, $5 .^{\circ}-A, 6 .^{\circ}, 7 .^{\circ}, 31 .^{\circ}, 45 .^{\circ}$, e $106 .^{\circ}$ do livro I, bem como os livros III e IV do EMFAR, aprovado pelo Decreto-Lei $n^{\circ} 34-A / 90$, de 24 de janeiro. Diário da República Série I. $N^{o}$ 200/2003, $2^{\circ}$ Suplemento (2003-08-30), 5752-(14)-5752-(73).

Decreto-Lei n. ${ }^{\circ}$ 236/1999 (1999). Aprova o estatuto dos militares das Forças Armadas. Diário da República Série I-A. No 236/99 (1999-06-25), 3792-3843.

Duchamp, J.-L. (1990). L'abandon de l'uniforme, essai d'interprétation. Le retour à la vie civile des cadres militaires titulaires d'une pension de retraite. Sociétés Contemporaines, 3, 131-144. doi: 10.3406/socco.1990.969

Giffen, M. B., \& McNeil, J. S. (1967). Effect of military retirement on dependents. Archives of General Psychiatry, 17(6), 717-722.

Gray, D. (2004). Doing research in the real world. Londres: Sage Publications.

Janowitz, M. (1975). Changing patterns of organizational authority. The military establishment. Em Military conflict: Essays in the institutional analysis of war and peace (pp. 221-38). Beverly Hills, California: Sage.

Johansen, R. B., Laberg, J. C., \& Martinussen, M. (2014). Military identity as predictor of perceived military competence and skills. Armed Forces and Society, 4(3), 521-545.

Kilpatrick, A. C., \& Kilpatrick, E. G., Jr. (1979). Retirement from the military: Problems of adjustment. Social Casework, 60, 282-288.

McNeil, J., Lecca, P., \& Wright, R. Jr. (1983). Military retirement: social, economic and mental health dilemmas. New Jersey: Rowman and Allanheld.

Ministério Defesa Nacional (MDN). (2015). Defesa 2020. Lisboa: MDN.

Moreira, C. (1994). Planeamento e estratégias da investigação social. Lisboa: ISCSP. 
Moskos, C. (1977). From institutional to occupation: trends in military organizations. Armed Forces and Society, 4(4) 41-50.

Moskos, C. (1986). Institutional and occupational: Trends in Armed Forces: An update. Armed Forces and Society, 12(3), 377-382.

Moskos, C. (2000). Towards a postmodern military?. Em S. A. Cohen (Ed.), Democratic societies and their armed forces (pp. 3-26). Londres: Routledge.

Nuciari, M. (1994). Rethinking the military profession: Models of change compared. Current Sociology, 42(3), 7-21.

Richter, G. (2017). Retention of medical officers in the German Armed Forces. Res Militaris, (5), 2-14.

Romão, A., \& Baltazar, M. S. (2015). Officiers au féminin de l'armée de terre au Portugal: Suivi des premières promotions. Em C. Weber (Dir.), Les femmes militaires (pp. 199-206). Rennes: Press Universitaires de Rennes.

Rosado, D., Romão, A., Baltazar, M. S., Fonseca, D., \& Lopes, H. S. C. (2017). Forças Armadas, cultura organizacional e valores partilhados: Estratégia, profissionalismo militar e desafios na gestão de recursos humanos do exército. Em Proceedings of the II International Meeting of ISSOW, Work, Professions and Organizatizions (pp. 331-347). Lisboa: APSIOT. Disponível em http://www.apsiot.pt/index.php/publicacoes.

Segal, M. (1999). Funções militares das mulheres numa perspetiva comparada: Passado, presente e futuro. Nação e Defesa, 88, 15-43.

Silva, M. N. (2017). O comportamento organizacional nas Forças Armadas. Em J. Vicente, \& A. Baltazar (Coord.), Cultura, comportamento e sensmaking (pp. 91-159). Pedrouços: IUM.

Sminchise, V. (2016). Military retention. A comparative outlook. Journal of Defense Resources Management, 7(12), 85-98.

Spiegel, P. E., \& Schultz, K. S. (2003). The influence of pre-retirement planning and transferability of skills on naval officers's retirement satisfaction and adjustment. Military Psychology, 15(4), 285-307.

Stanford, E. P. (1971). Retirement anticipation in the military. The Gerontologist, 1, 37-42. https://doi.org/10.1093/geront/11.1_Part_1.37

Sullivan, S. E., Carden, W. A., \& Martin, D. F. (1998). Careers in the next millennium: Directions for future research. Human Resource Management Review, 8, 165-186.

Szinovacz, M. E. (2003). Contexts and pathways: Retirement as institution, process and experience. Em A. G. Adams, \& T. A. Beer (Eds.), Retirement, reasons, processes and results (pp. 6-52). Nova Iorque: Springer.

Thomas, J. P., \& Rosenzveig, C. (1982). French NCOs: Career strategies and attitudes. Armed Forces and Society, 8(4), 275-301.

Tripathi, S. P. (2016). Retirement adjustment amongst the ex-servicemen. Psychology, 6(1), 488-490.

Warner, J. T. (2008). Thinking about military retirement. Alexandria, Virginia: The Center for Naval Analyses. 
Wilmoth, J. M., \& London, A. S. (2003). Life course perspectives on military service: An introduction. Em J. M. Wilmoth, \& A. S. London (Eds.), Life course perspectives on military service (pp. 1-18). Nova Iorque: Routledge.

Data de submissão: 03/05/2019 | Data de aceitação: 14/02/2020 